\title{
Deconstructing the nuclear family in Norwegian textbooks
}

\section{Desconstruindo a família nuclear nos livros didáticos noruegueses}

\author{
Susanne V. Knudsen ${ }^{2}$
}

\begin{abstract}
In this article the author presents how Norwegian textbooks in the 1990s and later make the nuclear family the norm of living together. The textbooks are for the secondary school in the curricula subjects of natural Science and environmental studies, social studies and home economics. The nuclear family in the chosen textbooks consists of the biological two-sex model and the cultural and social two-gender model. Some texts show the eagerness to present more than the heterosexual family life, and opens up to homosexuality both as sexual and social behavior. Single living is given little space in the textbook.
\end{abstract}

Keywords: textbook; family model; homosexuality.

\section{RESUMO}

Neste artigo a autora demonstra como os livros didáticos noruegueses, nos anos de 1990 e posteriores, fazem da família nuclear a norma de vida em comum. Os livros didáticos são dirigidos para o ensino médio, nos conteúdos curriculares de Ciências Naturais e Estudos Ambientais, Estudos Sociais e Economia Doméstica. A família nuclear, nesses livros didáticos, consiste no modelo biológico dos dois sexos e no modelo cultural e social de dois gêneros. Alguns textos demonstram uma vontade de apresentar algo além da vida familiar heterossexual, mostrando a homossexualidade como modelo sexual e social. Ao modelo monoparental é dado pouco espaço nos livros didáticos.

Palavras-chave: livro didático; modelo familiar; homossexualidade.

DOI: $10.1590 / 0104-4060.36466$

1 Texto publicado anteriormente no livro organizado por MATHES, Eva; HEICE, Carsten (ed.) Die Familie um Schulbüch. Bad Heilbonnin: Verlag Julius Klinkhardt, 2006. Esta publicação foi autorizada pelas organizadoras do livro.

2 Vestfold University College, Postbox 2243, N-3103. Tonsberg/Noruega. 


\section{Introduction}

In Norwegian textbooks for the secondary school issue in the 1990s and later the nuclear family is made visible in the subjects natural science and environmental studies, social studies and home economics for the $9^{\text {th }}$ and $10^{\text {th }}$ grades. Most of the textbooks are in accordance with the National Curriculum of 1997. The curriculum subjects as well as the textbooks stress gender equality as a question of valuing differences. However, the nuclear family seems traditionally connected to the two-sex model in the textbooks. The traditional presentations are connected to the opposing concepts boy/girl or man/woman and heterosexuality. How can the textbooks' dominating stories of the nuclear family with the two-sex model and the heteronormativity be deconstructed within the textbooks?

This article presents methodologies inspired by post-structuralism, gender and queer theories. It claims to use deconstruction to disturb and destabilize the traditional presentation of gender and sexuality. Gender is viewed as a matter of doing gender. Rather than reading gender as a biological essence (sex), gender is seen as unstable and in process. Inspired by the history of the one-sex and the two-sex model the article draws on research in how gender and sexuality could intertwine and disturb each other. In short the article presents the way the concept of the nuclear family is treated in the subject curricula of 1997.

Textbooks in natural Science and environmental studies for $9^{\text {th }}$ and $10^{\text {th }}$ grades are chosen, because chapters deal with nuclear family and the future nuclear family while also open up for different views on family living, gender and sexuality. To compare the construction and deconstruction of the nuclear family the most prominent textbooks in this matter are presented, i.e. textbooks in social studies for the $10^{\text {th }}$ grade and home economics for the $9^{\text {th }}$ grade. ${ }^{3}$

\section{Post-structuralism, gender and queer theories}

The way I use the concept deconstruction has been inspired by a modified post-structuralism. Pos-structuralism does not function as an independent theory, a coherent theory or a new theory. The concept of post-structuralism is

3 The textbooks in social studies for the $9^{\text {th }}$ grade focus on politics, civil rights and 'public' interests, not on 'private' and the nuclear family. 
a way of bringing different theories of knowledge and frames of interpretation or methodologies in play. The aim is to deconstruct in the sense of disturbing and destabilizing "the naturalized and the taking for granted", and to open up for changes (STAUNAES, 2003, p. 86, with references to SONDERGAARD, 2001; LATHER, 2000; DAVIES, 2000). Deconstruction means to "push" automatic connections and be "suspicious towards dictated meanings" (KNUDSEN, 2004a, p.46 with references to BUTLER, 1999; KNUDSEN, 2001, p. 221, with references to LATHER, 1992).

Deconstruction in this article is used to make us aware of the Western thinking in binaries or opposites like couple versus single, man versus woman, heterosexuality versus homosexuality. The binaries could be read as constructions where one side is valued as positive whereas the other side is valued as negative (LATHER, 1992; KNUDSEN, 2005). As Simone de Beauvoir made us aware, the man is valued as the norm and the absolute in favor of the woman who becomes the second sex (BEAUVOIR, 1949). Deconstruction is to turn the binaries upside down by placing them in reverse order in order to destabilize the negative concepts by giving them positive values, and vice versa.

In deconstruction of gender the concept of gender is read symbolically. Gender is made out of the reading of "the sign in the body", and the female and male values become a matter of interpretations and negotiations (SONDERGAARD, 1996). The woman and the female and the man and the male become what human beings in dialogue with the culture and the society make them. The two genders are social and cultural constructions expressed in language (MOI, 1994). With the queer theory the focus is on deconstructing the constructions of sexuality by challenging the two-gender model as based on heteronormativity.

Behind most queer theories and the deconstruction of heterosexuality stands Michel Foucault's Historie de la sexualité. La volonté de savoir (FOUCAULT, 1976/ 1978). In the book he demonstrates how heteronormativity is constructed of "the relationship between the married couple" and "the heterosexual monogamy" (FOUCAULT, 1978, p. 46-47; my translation from the Danish translation). Foucault argues that heterosexuality is becoming more unspoken and discreet during the eighteenth and nineteenth centuries. However, it is not less powerful and becomes even more normative in 'the unspokeness' and discretion. Visible and made sickly are, on the other hand, "the sexuality of the children, the insane and the criminal" as he formulates it (FOUCAULT, 1978, p. 48). The visible sexuality is observed and medicated as perverse. According to Foucault the concept of homosexuality was born in 1870 when pursuing the perverse sexuality. ${ }^{4}$

4 According to Foucault this is brought upon with the article "Die conträre Sexualempfindung" by C. Westphal (FOUCAULT, 1978, p. 52). 
Most queer inspired researchers are aware of how deconstruction of heterosexuality also influences the meaning of gender. The nuclear family can be viewed as born with the construction of the two-gender model in what the American professor of rhetoric and comparative literature Judith Butler names "the power regimes of heterosexism" (BUTLER, 1999, p. 42). When heterosexuality is tested, the gender trouble of the two-gender model is raised. However, queering heterosexuality and the two-gender model are also deconstructions towards more fluid ways of looking upon the hetero and homosexuality.

\section{Models of sex and gender}

In the book Making SEX. Body and Gender from Greeks to Freud the American professor of History Thomas Laqueur reads medical and philosophical literature to increase the development of a one-sex model into a two-sex model. Out of the historical reading comes an understanding of the biological sex as construed or interpreted. Where gender researchers in the Nordic countries have been aware of doing gender as cultural and social construction, Laqueur shows that sex as much as gender is represented. To him it is a matter of language and the eyes seeing the body that creates the biological sex as well as the cultural and social gender.

The one-sex model dominated the views of the male and female bodies until around the eighteenth century according to Laqueur. With this historical not very precise date he marks that although the two-sex model was still alive. In the one-sex model the male and female bodies are seen "as hierarchically, vertically" (LAQUEUR, 1992, p. 10). There is only one body in this view, the male body. The female body is seen as a male replica. The vagina becomes a penis and the uterus as scrotum. With medical drawings Laqueur shows the ways organs on the body could be read as shifting signs. In the one-sex model a body with breasts is provided with organs corresponding to the body with chest, and a torso with female breasts has a "penis-like vagina" (LAQUEUR, 1992, p. 78, 83). Such signs on the bodies could be interpreted as ways of creating equality between the male and the female. That would be the positive reading of making sameness out of the female and male bodies. However, Laqueur is more negative on behalf of the women. In the one-sex model the woman is a less perfect man, having "exactly the same organs but in exactly the wrong places" (LAQUEUR, 1992, p. 26). The woman is described as being less hot than the man, and she is less well-formed, more problematic and unstable. When the female body designed 
as protean, it opens for being a female in a male model, and it could change into the two-sex model towards a female in a female model. In both models the male body is the stable with the same signs (penis and scrotum) on the body. As gender researches have accentuated, the stable sex of the man is a matter of the cultural and social construction of gender neutrality (KORVAJÄRVI, 2001; KNUDSEN, 2004b). The woman has a gender whereas the man is genderless.

Laqueur shows that the interpretation of the one-sex model can be connected to the power and legitimacy of fatherhood: "The one-sex model can be read, I want to suggest, as an exercise in preserving the Father, he who stands not only for order but for the very existence of civilization itself." (LAQUEUR, 1992, p. 58). In my reading of the fatherhood, the family with the father in the center as the superior points towards the patriarchal father in the one-sex model.

With the two-sex model the male and female bodies are seen as "horizontally ordered opposites" (LAQUEUR, 1992, p. 58). In words and illustrations the bodies are read as signs of two fundamentally different sexes. The female and male genitalia are separated, and the vagina gets a name of its own. The reproductive woman and motherhood becomes the focus of attention. This could be interpreted as equal-worth, and so it has been within parts of the women's movement around 1900 as well as in the 1970's feminist movement. In Laqueur's view the two-sex model confirms the problematic instability of the female body.

In the separation of the sexes the heterosexuality is pushed forward: "Thus in the two-sex model, as before, the generative substance in both men and women were believed to be produced only during intercourse" (LAQUEUR, 1992, p. 184). The two sexes are interpreted as opposites with female versus male, and with for example emotion versus reason, nature versus culture. In my view the transition from the one-sex model to the two-sex model seems to make the social and cultural gender of topical interest. It is not only a matter of biological sexes and of mother and fatherhood. Rather the mother and the woman as well as the father and the man are categorized as genders with specific feminine and masculine values. In the nuclear family the woman's femininity becomes a characteristic of the present mother. The fatherhood could still be concentrated on the patriarchal father, who could be named "the hegemonic masculinity" and the hegemonic father (CONNEL, 1995). However, through the eighteenth centuries the image of the absent father is formed in the nuclear family (SHORTER, 1975). The absent father could still be formed as the patriarchal father with hegemonic power. Fatherhood becomes rather powerful as "norms, values and structures" however (JOHANSSON, 2003, p. 26; my translation). The absent father is the working father. From the 1960s the absent father in the Nordic societies is combined with the families without fathers. The father disappears into professional life and out of the nuclear family in the growing 
rate of divorces. The single mother with the children and the single man without the children appears in the statistics. As a contrast to this development the caring father is highlighted as the new fatherhood in the late twentieth century (JOHANSSON, 2003). The caring father takes place in a nuclear family with parents equally sharing child-rearing, and he gives "a specific ability of care" (JOHANSSON, 2003, p. 34).

\section{97: The Norwegian National Curriculum}

In different ways the Norwegian National Curriculum of 1997 explains how the nuclear family is combined with the two-sex model, the two-gender model and the heterosexuality. In the curriculum subject for natural science and environmental studies the focus is on body and health in which the nuclear family is involved. The students should be introduced to questions connected to human reproduction, to the sexual identity of gender. In the $5^{\text {th }}$ grade, the students must "work with questions connected to puberty, and the role of the puberty for human reproduction and sexual identity of gender, among others heterosexual/ homosexual" (LAEREPLANVERKET..., 1997, p. 211). According to the curriculum subject for natural science and environmental studies the students are not to work with these questions again before the $10^{\text {th }}$ grade. In the $10^{\text {th }}$ grade the students have to be familiar with the reproduction, fertilization, menstruation period, contraception, sexual transferred illness and abortion. In addition the students should discuss love, care, sexuality, homosexuality, minimum age of sexual débuts, and sexual harassment (LAEREPLANVERKET..., p. 217).

The nuclear family is not named as such in the subject curriculum for natural science and environmental studies neither for the $5^{\text {th }}$ nor for the $10^{\text {th }}$ grade. Between the lines, however, the reproduction, fertilization, contraception and abortion point toward the heterosexual couple. The nuclear family stands as the implicit structure, and by not explicitly mentioning it, it has become the dominating norm. As the focus is the body and health, the implicit nuclear family is closely connected to the biological sex and the two-sex model. Furthermore, there is a specific focus on the woman as sex by mentioning her menstruation period, and different forms of physical abortions (spontaneous and induced). When it comes to knowledge about contraception and sexual transferred illness, love and care, the language constructs a gender neutrality. The gender neutrality is also in the foreground when it comes to the $9^{\text {th }}$ grade. Although the curriculum does not state that the students in the $9^{\text {th }}$ grade should work with 
the questions of human reproduction and sexual identity of gender, they have to acquire knowledge about "how the skeleton, joints and muscles function together" and "how the endocrine system controls the single process in the body" (LAEREPLANVERKET...,p. 216). By the way, the text about the skeleton and the endocrine system has been formulated, the students are indirectly asked to acquire knowledge from a one-sex model and gender neutrality. In the $5^{\text {th }}$ and $10^{\text {th }}$ grades the dominating heterosexuality in the curriculum is complied with mentioning both hetero and homosexuality. The visibility of homosexuality could be read as a step towards deconstructing the dominating heterosexuality. The possibility of two forms of sexuality is mentioned as "among others". In the $10^{\text {th }}$ grade some different possibilities in working with sexual identity are discussed: the physical sexuality, the question of sexual débuts and sexual harassment. However, only two physical sexualities are mentioned; hetero and homosexuality.

When it comes to social studies and home economics, the curriculum explains the family from the beginning of history. In social studies under the section of "Human beings and societies before us" for the $1^{\text {st }}$ grade the students should work with "pictures of the family" (LAEREPLANVERKET..., p. 178). In the $4^{\text {th }}$ grade "girls and boys, women and men in home and society" have to be discussed under the section of "Individual and society" (LAEREPLANVERKET..., p. 180). From the $5^{\text {th }}$ to the $7^{\text {th }}$ grade the family is described as "the small society" (LAEREPLANVERKET..., p. 181). Knowledge of the family is connected to parents and children in the $5^{\text {th }}$ grade; puberty and sexual identity in the $7^{\text {th }}$ grade. The family is named as such in the $8^{\text {th }}$ and $10^{\text {th }}$ grades. In the $10^{\text {th }}$ grade the students have to learn about the changes in "structure of the family", "the economy of the family", and "sexuality, cohabitation, marriage and partnership" (LAEREPLANVERKET..., p. 186-87). The parallel between cohabitation, marriage and partnership opens up to different family forms. As in the curriculum subject of natural science and environmental studies, however, the curriculum subject of social studies in its preliminary section puts forward the nuclear family as the implicit family form.

In the curriculum subjected of home economics under the section "The children and the family", the family is connected to having children. Home economics should without doubt concentrate on the home with a two-sex model and a two-gender model. The students shall from the very first school years learn about different roles, equal-worth and equality in the home. From the $8^{\text {th }}$ grade to the $10^{\text {th }}$ grade the section "Care and the social action" tells the students to work for "equal-worth and equality at the home and in the school" (LAEREPLANVERKET..., p. 259). 


\section{Natural science and environmental studies for the $9^{\text {th }}$ and $10^{\text {th }}$ grades}

The Norwegian textbooks Helix 9 and Helix 10 for natural science and environmental studies are written by the cooperation of four authors, two with men's names and two with women's names (ISNES et al., 1998; 1999). In the textbook for the $9^{\text {th }}$ the introductory illustration, which extends across two pages, shows a heterosexual couple in a forest. The man hunts the deer, and the woman picks the berries. The man and the woman are together in nature, although separated. He is hunting in the background of the picture with his face hidden behind the gun, and she is working is the foreground with her face fronting the students. The illustration is a constructed still-picture, where nature is stopped in its movements. The nature is presented as if it has always been constituted of deer, animals, and human beings of two separated genders. The text tells the students that they are introduced to "The forest". The following pages refer to this illustration. The text is about the forest as an ecological system. The ecology consists of trees, plants, animals and human beings. The construction of the masculinity and the femininity from the starting illustration is repeated in a close-up of the hunting man and the berry picking woman, when they are introduced in the text. However, in the text the genders are not mentioned. In principle the text could be read as genderless, and the students may possible imagine the reverse order of the gender with the woman hunting deer and the man picking berries:

There are also people in the forest. One of them picks the berries and eats, and when that happens the nourishment chain becomes very short: From bilberries to human being. Another person is hunting. The hunter shoots a deer. The meat from the deer is tasty food for many human beings. The deer takes nourishment from the plants. This time the nourishment chain becomes a little bit longer: From plants to deer to human being. (ISNES et al., 1998, p.14).

As the unmentioned nuclear family in the curriculum subject stands as the implicit structured and strengthen the dominating norm, the two-gender model is stated as the norm of the ecological system. Furthermore the illustration anchor the two-gender model and makes the reverse order invisible for the students to read or imagine. The last chapter in the textbook underlines the two-gender model and the heterosexual regime in the introduction. Although the last chapter 
is about intoxication (cigarettes, alcohol, drugs), an illustration shows happy young heterosexual couples dancing and sitting close together in a private party at Kari's (female name). The text reposts that they are having a sober party: "They are dancing and talking, they are listening to music, telling stories and having great fun... Some of them are moving a little away from the others to cuddle each other" (ISNES et al., 1998, p. 234). In contrast to this illustration and text, another illustration and text refer to a private at Ole's (a male name) where the young heterosexual couples have had too much alcohol. The text reports that the young after drinking and taking drugs do not care who they are making with, although a gender difference is registered: "Some of the girls are pressed to partake in sex with the boys. If a boy does not get what he wants form one girl, he can find others who are willing." (ISNES et al., 1998, p. 233-34).

Where the nuclear family in nature is represented as trans-historical, the ideal of the future nuclear family is pointed out without alcohol and drugs, and without physical pressure on sexuality. In the first and the last chapters of the textbook the combination of illustrations and texts with no doubt creates an awareness of the heterosexual living. The heterosexuality is constructed by the help of the male and the female. However, the two genders are valuated differently in the introduction and in the conclusion. In the nature and trans-historical introduction the man's gender is more positive than the woman's; he is constructed as part of the nourishment chain with three steps while the woman only has two. On the contrary, in the conclusion of the textbook, where the female gender is highly valued for its popularity and moral at the expense of the male gender who allows his guests to drink and smoke hashish, and make love at home. Between the introduction and the conclusion more chapters confirm the nuclear family, the two-gender model and the heterosexuality as the norm of the textbook. However, the norms are also deconstructed with a one-sex model.

The one-sex model comes into focus in the presentations of the genderless skeleton. The illustrations of skeletons probably belong to the male gender. They have big shoulders and hip sockets without curves. In the text the gender is not spoken of, and in this way it becomes even more powerful. The one-sex skeleton is taken to mean the male body, and becomes a powerful signal for manhood. Following this hierarchical focus on the male body at the expense of the female body, the textbook shows the male as the human brain, as a human being with nerve cells and the endocrine system. When the endocrine system is presented as a matter of thyroid hormone, growth hormone and stress hormone there is only one unspoken gender. However, when it comes to the endocrine system the two-sex model also deconstructs the one-sex model. In illustrations and words the reproductive hormones are made a matter of the female sex "responsible for the start of puberty and development of the reproductive organs" 
(ISNES et al., 1998, p. 72). In the foreground come the ovaries and the testicles, and the motherhood is shown with an illustration of a breastfeeding baby. Both models are presented with complete naturalness, and are equally emphasized in the textbook, but they could also be read as competing models. The two-sex is the dominating norm in the sense of constructing equal-worth out of traditional biological sexes. However, the one-sex model tries to dominate in constructing equality and sameness.

The textbook Helix 10 with focus on body and health follows to a great extent the curriculum subject. Extracts form the curriculum is presented, although in a different order. The textbook starts where the section for body and health in the curriculum ends. In the textbook the students are from the very first text lines told to discuss the concepts of love, care, sexuality, sexual gender identity "among others heterosexuality, homosexuality, minimum age of sexual débuts, and sexual harassment" (ISNES et al., 1999, p. 143). The text is illustrated with a photo showing a newborn child in the hospital with its mother and father. The mother is connected to the reproductive mother with a crying baby on her stomach, whereas the male is pictured as concentrated on taking care of the female. The heterosexual couple is shown as the female and the male wrapped in each other. Neither one looks at the baby. The female has the weight of the baby on her stomach, however, whereas the male neither looks at nor touches the baby. Although the male is present in the situation, the father seems absent.

In illustrations of nudity a girl and a woman, a boy and a man are presented. The naked females are followed up by illustrations of the vagina and a text telling that the genitalia consist of both inner and outer parts. When it comes to the naked males the illustration and text explain that the penis is placed outside the body. The illustrations construct the two-sex model with the girl belonging to the mother and the boy belonging to the father. The differences between the two sexes are not only a matter of biology. They are also constructed as parents in a heterosexual regime where the cultural and social two-gender model occurs as binaries. The son belongs to the father, and the daughter to the mother, so they have different signs on the body and maybe opposite interests?

After several pages that concentrate on heterosexuality and the reproduction of human beings, the students are introduced to homosexuality. In the text homosexuality is mainly defined as sexuality between men, starting in ancient Greece, informing of homosexuality in Norwegian legislature. The text is supplemented by a photo showing two men of different races. The students could ask why the focus is on male homosexuality, and why female homosexuality is only mentioned in connection with the organization of female lesbian and male homosexuality, and why male homosexuality has to be illustrated with different races. In framed, green coloured text the female and male homosexuality 
is explained, and the concepts of bisexuality and transvestism are introduced. The summary of the chapter highlights the two-sex model and the two-gender model, and points towards the heteronormativity and the nuclear family as the most important story to tell. However, the homosexual could disturb the naturalized heterosexuality. The very last words tell the students: "No one should be discriminated against his or her sexual preferences" (ISNES et al., 1999, p. 172).

\section{Social Studies for the $10^{\text {th }}$ grade}

Two textbooks for social studies in the $10^{\text {th }}$ grade are written in accordance with the curriculum subject (MIKKELSEN et al., 1999; BLOM; BJORSHOL, 1999). In Samfunnskunskap 10 - Verdier og valg (Knowledge of the society 10 values and choices) by Mikkelsen et al. the chapters about "The economy of the family", "Living together and difficult choices", "Forms of living together" and "Gender roles and equality" are mainly focused on the nuclear family. Although, "the economy of the family" is told in a gender neutral language, Norway is described as a society with "the ordinary family consisting of two adults and two children" (MIKKELSEN et al., 1999, p. 32). The "two adults are so obviously of different genders, that there is no point in mentioning it in the text. There are the unmentioned female and male: "Most persons fall in love with a person of the opposite sex" (MIKKELSEN et al., 1999, p. 38). The normal heterosexual two-gender nuclear family is followed by stories of hope for falling in love and marriage. Furthermore the textbook reports on being pregnant, having children, abortion, and give statistics of annual marriages, divorces and separations in different regions of the country.

However, the authors of the text are eager to mention other forms of living: "Remember that many, very many families are of different form [...]". They state that the two-gender heterosexual living is a "heterosexual creation", and that there are other options such as "homosexual" and "bisexual" relationships (MIKKELSEN et al., 1999, p. 32, 38). The students are told that homosexuality is neither sickness nor "infectious", and that both girls and boys can be homosexual. The difference between the concepts of marriage, cohabitation and partnership is described. The text about the partnership explains that homosexuals need to live with unambiguous norms parallel to married people. It goes on telling the students that homosexuals are not allowed do marry and adopt children.

The illustrations are kept to a minimum in the textbook by Mikkelsen et $a l$., and only a few illustrations show the heterosexual couple. In the text and in 
the few illustrations homosexual living is legitimate, and the text deconstructs the myth about homosexuality as sick and perverse. Furthermore the questions and tasks for the students shift between placing the homo and heterosexual in the back to nuclear families by giving most space to the two-gender model and the heteronormativity. The textbook is also true to the curriculum subject in having the main focus on the nuclear family as well as describing other family patterns.

However, in the same way as in the textbook Helix 10, the homosexual in Samfunnskunskap 10 - Verdier og valg is illustrated by male homosexuality of different races. Such illustrations could be used to trouble the white Norwegian heterosexuality. It could be an indicator of how testing heterosexuality makes gender trouble as Butler writes. To deconstruct the nuclear heterosexual family the Norwegian textbook has underlined the otherness. It has to show other ways of living by connecting the male homosexuality to the question of race. The ways of troubling heterosexuality in the illustrations of homosexuality could make the students aware of equal-worth and equality as a matter of sexuality, gender and race. Illustrations that differ essentially from the concept of the heterosexual nuclear family could, on the other hand, possibly enhance the perception of the difference the students are confirmed and not challenged in the heteronormative presentation of the Norwegian nuclear family. The textbook is open to both ways of seeing it, and could be used as a way of discussing the normal Norwegian white two-gender nuclear family form.

In Samfunnskunnskap 10 (Knowledge of the society 10) by Blom and Bjorshol the ideal way of living together is a result of the heterosexual church marriage between male and female. The chapter "Living together, choices and values" starts with the words: "Everyone needs to love and be loved, to give care and to be cared for, to experience intimacy and membership" (BLOM; BJORSHOL, 1999, p. 34). The genderless opening states the powerful unspoken heterosexual two-gender model, and a painting illustrates that "Everyone" consists of female and male genders. With the headline "Birds of feather flock together" the love between a man and a woman in a poem and the Bible is focused upon as an example for the students. Rather than introducing the question of gender and sexuality, the text and illustrations in the textbook prefer the presentations of disability and ethnicity. The text is, for example, illustrated by a young two-gender couple with Down's syndrome and a wedding in India.

In the textbook the concepts of cohabitation, marriage and partnership follow the curriculum subject. The differences between cohabitation and marriage in a heterosexual life and partnership are, however, not explained. The concept of sexuality is introduced afterwards and as a following up of the above mentioned concepts. When it comes to marriage the church marriage is placed before the marriage at a registry office, and the illustration follows the hierarchy 
of marriage in showing a bride in a white wedding dress and the groom in a black tuxedo. This illustration is placed between the text that explains the differences between marriages at a registry office and registered partnership. If the students do not know the concept of partnership, they may interpret partnership as belonging to the two-gender model. In the following up questions, tasks and discussions on cohabitation and marriage are the only form mentioned. To figure out that partnership is connected to homosexuality the students have to move to the next section: "Sexuality - interaction and responsibilities". Partnership is interpreted as a sexual relation, and hence different from cohabitation and marriage. Furthermore, the text states that the homosexuality to a large extent belongs to "adolescence", and can be seen as a way of "exploring sexuality" (BLOM; BJORSHOL, 1999, p. 44).

The textbook Samfunnskunnskap 10 by Blom and Bjorshol is structured around a hierarchy. At the top of the hierarchy church marriages between heterosexual couples are presented. Church marriage is the life goal for the people of Norway. While young the females and males can live together without being married. However, the ideal is to be married with the opposite gender. Teenagers may be attracted by the same gender, but it is only a matter of sexuality, not love, and homosexuality is understood as a less perfect form of sexuality than the heterosexuality.

Both textbooks in social science for the $10^{\text {th }}$ grade are examples of how the nuclear family becomes constructions of heterosexuality and the two-sex model towards giving birth to children and the two-gender model in the family life. The different orders in which the texts are presented in the two textbooks give the impression of how the order guides the interpretation. Whereas the textbook by Mikkelsen et al. may open up for the deconstruction of the heteronormativity in the Norwegian families, the textbook by Blom and Bjorshol explains heterosexuality as the natural form: "For most girls and boys it is natural to be attracted by the opposite gender" (BLOM; BJORSHOL, 1999, p. 48).

\section{Home economics for the $9^{\text {th }}$ grade}

In the Heimkunnskap (Home economics) for the $9^{\text {th }}$ grade the text gives advice on family life, and good ways living in the nuclear family (SKJOLD et al., 1997). The textbook is written by four authors, two with men's names and two with women's names. Most of the textbook is written in a gender neutral language. However, several drawings show the two genders and the two-gender 
model in the heterosexual, nuclear family. In the drawings the males and the females share family responsibilities with healthy food, dish washing and cleaning. Some of the drawings are caricatures of the male gender. There is for example a caricature of a person in a business suit and tie, reading a newspaper and thinking "cleaning again?!" (SKJOLD et al., 1997, p. 225). However, most of the illustrations stress the male gender as taking part in the family doings with cleaning, cooking and caring for the children.

The drawings construct the father as a present and careful father in the nuclear family. The father is the person who walks with the pram, calms the smallest baby and makes fun with the eldest child (a boy, judging by the hair cut) (SKJOLD et al., 1997, p. 266). The text "being parents is a great responsibility" is illustrated with a father holding a child, making the child laugh. The mother, on the other hand, is absent in the textbook, as long as it comes to illustrate how to take are of children. Instead the female is for example presented in a drawing with parents and their two children while the text informs us that she is the organizer of the bank loan, the house rent, the insurance, and money for food and clothes. She writes the family's book and is the active part in handling the money. On the other hand, the father is dreaming of a car; the daughter is considering becoming a student, and the son is longing for sweets. The drawing and its caption deconstruct the traditional functions of the female in the home when she is made responsible for the family economy. The male is portrayed as the family member who is more occupied with cars than the family's economy. The portrayed male could be read by students as a way to destabilize the traditional patriarchal or hegemonic and masculine father. The father is revealed as a rather egoistic person who is interested in his own and traditional masculine dream of a car only. Although the father is present in the illustration, he is rather absent in his dream, and he is dressed in the habitual, white shirt with a tie that shows him as the male coming home from work. On the other hand, the unconventional femininity is connected to the family life. She is not coming home from work, and she is the present mother in the family's economic matters.

The nuclear family is the standard pattern in the illustrations in the textbook for home economics. Hereby the students are made the nuclear family readers, the heterosexual readers, and the two-gender readers of traditional gender categories. The caricatures can be read as a deconstruction of the two genders in the nuclear family. But the nuclear family is not in question on the textbook.

The progress of the chapter "Care and social action" in Heimkunnskap confirms the narrative of the nuclear family. However, the nuclear family is to certain extent destabilized under the presentation of marriage. The marriage is undoubtedly focused on a male and female couple, the bridegroom and the bride. 
The text relating to marriage is followed by information about the conditions of cohabitation, partnership and how the law of partnership is meant to secure the rights of registered homosexual partners. But further on in the chapter there is an illustration of a bride and bridegroom facing front on the top of the page. Underneath is an illustration of a homosexual couple with female body signs. If the set up of a page illustrates priority, the nuclear family is placed in a hierarchy above the homosexual partnership. Furthermore, the heterosexual couple is to be viewed from the front with the faces towards the viewers, whereas the lesbians turn their back to the viewers as if they are moving out of the picture and the narrative.

Towards the end of the chapter and the textbook the text focuses on "The single", this time without any illustration. A facsimile of an advertisement for The National Organization of Singles ("Ensliges Landsforbund") is the only supplement to the text. The text reads:

Singles constitute a considerable group in the society. Around $45 \%$ of the Norwegian population belongs to this concept. The concept single is used about a grown up person who is not married, and who does not live in a registered partnership or cohabitation.

[...] The Singles have the same right as others to a home where they are doing without problems and do have space for visiting families and friends, and where guests can stay overnight. You have to be able to do without problems yourself, if you are going to live a life by your own. At the same time single living includes more freedom compared to persons in various kinds of partnerships $[\ldots]$

The large amount of single living persons $-45 \%$ of Norwegian adults are single - makes it visible that the main focus in the textbook is biased. Only one page out of more than 280 pages informs the students of single living persons. In the arguments for the single living's "equal rights", the words that are used form a parallel to the nuclear family with "home" and "space". Although the hetero and the homosexual seem to have the right to a home and a space, the totally of the textbooks creates the picture of nuclear heteronormativity. The paradox is that the nuclear family only consists of $55 \%$ or less of the adult population. The homosexual partnerships are given no space at all in the textbook, and are not treated as a group. However, both the homosexual and the singles mentioned in the textbook may open up for deconstruction of the heteronormative sexuality in the nuclear family. 


\section{Conclusion}

The Norwegian textbooks from the 1990s make the nuclear family the norm of living together. The nuclear family consists of the biological two-sex model and the cultural and social two-gender model. The family is constructed around a couple in "a powerful regime of heterosexism" (BUTLER, 1999). In some textbooks the nuclear family with the heterosexual and two-gender model is visible for the students; in other textbooks the sexual and gender norms of the nuclear family are implicit, and by not making it explicit the dominating norms become rather strong.

In the textbooks for the subject natural science and environmental studies for the $9^{\text {th }}$ and $10^{\text {th }}$ grades; social studies for the $10^{\text {th }}$ grade and home economics for the $9^{\text {th }}$ grade the nuclear family is presented in chapters as the subject curricula of 1997 requests. However, there are examples of different interpretations of the curriculum in the textbooks. In one textbook the nuclear family form is interpreted as a couple married in the church. Another textbook seems to be more open for dialogues about marrying in a church or a registry office. Some texts show the eagerness to present more than the heterosexual family life, and open up to homosexuality both as sexual and social behavior. Single living is presented in one textbook, although giving little space, and construed as opposite to nuclear family life.

The textbooks are dominated by the two-sex model when the biological sexes are introduced. The texts and illustrations highlight the female reproduction and the coming motherhood. By doing so the female is constructed with a femininity connected to motherhood, and the female is made a gender. The male could be genderless in the two-gender model, and in the figures of skeletons the male is the norm, and the female is protean, changing form, being similar to the male and doing gender as a female. Especially in motherhood, femininity is constructed as the present gender in the present motherhood. However, in the textbook for home economics the instable fatherhood and the protean masculinity are on stage. The father is introduced in drawings as both the present and as absent male. In the textbook equality is stressed in some of the drawings by making the gender oppose to common norms.

With the identification of binaries in the textbooks the students may start the deconstructions of: the nuclear family versus the single family, heterosexuality versus homosexuality, bisexuality, transexuality, the two-sex versus the onesex model, and the two-gender versus the one-gender model. They may start to reflect on the reverse order, for example when the textbook states that the single 
family may experience "much more freedom" than the two opposite sexes or genders in the nuclear family. Most textbooks inform the students that nuclear families may end in divorce. The construction of one sex or one gender may lead to the genderless equality, whereas living with the two sexes or two genders may lead to devastating rows. On the other hand, the two genders could make a joyful living with differences instead of sameness. The genders may merge, which destabilizes the mother and fatherhood in the textbook illustrations. The father may be present as well as absent, and this may apply to the mother as well. The deconstruction of the nuclear family with its norms of sexuality, sex and gender is not obvious in the selected textbooks. However, the possibilities of doing other family forms are like pop-ups in the textbooks, if the students and teachers are ready to grasp them.

\section{REFERENCES}

BEAUVOIR, Simone de. Le deuxieme sexe. Paris: Gallimad, 1949.

BLOM, Kari; BJORSHOL, Stig. Samfunnskunskap 10. Oslo: Aschehoug, 1999.

BUTLER, Judith. Gender trouble. New York: Routledge, 1999.

CONNEL, Robert. Masculinities. New South Walles: Allen \& Unwin, 1995.

DAVIES, Bronwyn. (In)scribing body/landscape relations. Oxford: AltaMira Press, 2000.

FOUCAULT, Michel. Seksualitetens historie. Kobenhavn: Rhodos, 1978.

ISNES, Anders et al. Helix 9. Natur- og miljofar for 9. klasse. Oslo: Cappelen, 1998.

ISNES, Anders et al. Helix 10 Natur- og miljofar 10. klasse. Oslo: Cappelen, 1999.

JOHANSSON, Thomas. Den kluvna fadersbilden. Kultur, identitet och kropp. In: BÄCK-WIKLUND, Margareta, et al. (Eds.). Den dolda könsdiskursen om mödar, söner och franvarande fader. Stockholm: Migra Grafiska AB, 2003.

KNUDSEN, Susanne V. Kan graesset blive for gront? Metodologiske oververjelser I forbindelse med forskning med/ i kvalitative data og kon. In: REISBY, Kristen. (Ed.). Konsblik-pa bacheloruddannelsen. Copenhagen: The Danish University of Education, 2001.

KNUDSEN, Susanne V. Flere kon I folkeskolen. Kvinneforskning, Oslo, n. 3, 2004a.

KNUDSEN, Susanne V. Gender paradoxes and power - theoretical reflections with empirical awareness. NORA, n. 2, 2004b. 
KNUDSEN, Susanne V. Dancing with and without gender. Reflections on gender, textbooks and textbooks research. In: HORSLEY, Mike; KNUDSEN, Susanne V.; SELANDER, Staffan (Eds.). Has past passed? Textbooks and education media for the 21th century. Stockholm: Stockholm Library of Curriculum Studies 15, 2005.

KORVAJÄRVI, Päivi. Gender-neutral. Gender and denial of the difference. In: CZARNIAWSKA, B.; HÖFPL, H. (Eds.). Casting the other. The production and maintenance of inequalities and equalities in work organization. London: Routhledge, 2001.

LAEREPLANVERKET for den 10-arige grunnskolen (The Norwegian National Curriculum for the 10 year primary and secondary school). Oslo: Det kongelige kirke-, utdanning- og forskningsdepartementet, 1997.

LAQUEUR, Thomas. Making SEX. Body and gender form Greeks to Freud. Cambridge: Harvard University Press, 1992.

LATHER, Patti. Critical frames in educational research: feminist and poststructural perspective. Theory and Practice, n. 2, 1992.

LATHER, Patti. Against voice, authenticity and empathy. Kvinder, kon \& forskining (Women, gender \& research), n. 4, 2000.

MIKKELSEN, Rolf et al. Samfunnskunskap 10. Verdier og valg. Oslo: Cappelen, 1999.

MOI, Toril. Simone de Beauvoir. The making of an intellectual woman. Oxford: Blackwell Publishers, 1994.

SHORTER, Edward. The making of the modern family. New York: Basic Books, Inc., 1975.

SKJOLD, Gunnar et al. Heimkunnskap 9 klasse. Oslo: Det norske Samlaget, 1997.

SONDERGAARD, Dorte Marie. Tegnet pa kroppen. Kobenhavn: Museum Tusculanum, 1996.

SONDERGAARD, Dorte Marie. Destabiliserende diskursanalyse. Veje ind I poststrukturalistisk forskining. In: Kjonn of fortolkende metode. Oslo: Gyldendal Akademinsk, 2001.

STAUNAES, Dorthe. Etnicitet, kon og skoleliv. Doctoral dissertation. Roskilde: The University Center of Roskilde, 2003.

Texto recebido em 09 de maio de 2014.

Texto aprovado em 19 de maio de 2014. 